\title{
canom \\ Correction: Lippe et al. Estimating Global Forest-Based Employment. Forests 2021, 12, 1219
}

\author{
Rattiya Suddeephong Lippe ${ }^{*,+} \mathbb{D}$, Shannon Cui ${ }^{\dagger}$ and Jörg Schweinle ${ }^{\dagger}(\mathbb{D}$ \\ Thünen Institute of International Forestry and Forest Economics, 21031 Hamburg, Germany; \\ shannon.cui@thuenen.de (S.C.); joerg.schweinle@thuenen.de (J.S.) \\ * Correspondence: rattiya.lippe@thuenen.de \\ † Current Address: Thünen Institute of Forestry, 21031 Hamburg, Germany.
}

Citation: Lippe, R.S.; Cui, S.;

Schweinle, J. Correction: Lippe et al.

Estimating Global Forest-Based

Employment. Forests 2021, 12, 1219.

Forests 2022, 13, 30. https://

doi.org/10.3390/f13010030

Received: 9 December 2021

Accepted: 16 December 2021

Published: 28 December 2021

Publisher's Note: MDPI stays neutral with regard to jurisdictional claims in published maps and institutional affiliations.

Copyright: (C) 2021 by the authors. Licensee MDPI, Basel, Switzerland. This article is an open access article distributed under the terms and conditions of the Creative Commons Attribution (CC BY) license (https:// creativecommons.org/licenses/by/ $4.0 /)$.

In the original publication [1], there was a missing word in the caption of Table 5 Comparison our employment estimates (person FTE) with the prior studies. The word "million" is missing in the unit presented in the table caption. The corrected Table 5 appears below:

"Table 5. Comparison our employment estimates (million-person FTE) with the prior studies."

The authors apologize for any inconvenience caused and state that the scientific conclusions are unaffected. The original publication has also been updated with reference to this correction.

\section{Reference}

1. Lippe, R.S.; Cui, S.; Schweinle, J. Estimating Global Forest-Based Employment. Forests 2021, 12, 1219. [CrossRef] 